\title{
Globes and Teaching Aids Manufactured by Jan Felkl Company for the Polish Market
}

\section{Malgorzata Taborska}

\author{
Museum Collections Department \\ of the Jagiellonian University Museum \\ Jagiellonska 15, \\ Kraków 31-010, Poland \\ E-mail: malgorzata.taborska@uj.edu.pl
}

\begin{abstract}
Jan Felkl company from Roztoky (Roztok) near Prague manufactured globes in seventeen language versions, since 1861 also in Polish language. The company was active until 1952, but it ceased to manufacture Polish-language globes as early as in 1914. In the aftermath of the First World War, and with the development of printing business, the demand for Czech globes shrank. It is difficult to estimate the overall output of Polish-language globes manufactured by Felkl's company throughout the 53 years it operated. From catalogues and the surviving globes we know that terrestrial globes in six sizes, folding globes in two sizes, celestial globes (probably in four sizes), as well as telluria, lunaria and planetaria were manufactured for the Polish market. It is difficult to decide how many editions of individual types of globes were issued. Polish names were compiled by Franciszek Waligórski (one globe) and Mirosław Suchecki.

Only 28 globes have survived to this day, including one celestial globe. Most of them are globes of an 8-inch diameter, approved by the Austrian ministries as teaching aids for schools. Nearly half of the surviving globes date from the years 1894-1914. Only ten items are in museums.
\end{abstract}

Keywords: globe, Jan Felkl company, Polish-language globes

\section{Introduction}

Today, teaching aids may be seen in every school, but in the $18^{\text {th }}$ century they were not so popular. The earliest globe which might have been used as a teaching aid in Poland was the one manufactured by Hans Dorn in Buda (1480). Since 
1494 , it is owned by the Jagiellonian University and is now on display at the Jagiellonian University Museum ${ }^{1}$, along with a pair of Gerard Mercator's globes (1541 and 1551), purchased for the University in the $16^{\text {th }}$ century. They are ranked among the earliest surviving globes used in Poland as teaching aids. Several dozen globes from former higher schools, Jesuit colleges, etc. have survived in Polish collections. ${ }^{2}$ Globes with Polish-language maps began to be manufactured not earlier than in the mid-nineteenth century. The oldest were made by the Nuremberg-based Abel-Klinger's company in the years 1840-1860. ${ }^{3}$ Currently we know five of its products: three $15 \mathrm{~cm}$ in diameter, two $21 \mathrm{~cm}$ in diameter (the Jagiellonian University Museum) and one $c a .10 \mathrm{~cm}$ in diameter (part of a private collection) ${ }^{4}$. Historically, the second one was Jan Felkl's (1817-1887) company, based in Prague, which published Polish-language globes since 1861.

\section{History of Jan Felkl's company}

The company was founded in 1852 and was the largest business of this type in the Austrian Empire (Table 1). Initially it was based in Prague, and in 1870 moved to Czech Roztoky on the Vltava, a small locality situated a little less than 10 kilometers north of Prague. The company existed until 1952, all the time managed by the Felkl family. Jan Felkl presented his globes at international exhibitions, including Paris (1867) and Vienna (1873), winning numerous awards and medals. The company experienced two periods of boom-as a young business under Jan Felkl and in the years 1894-1914 when it was managed by Ferdinand Felkl (1846-1925), Jan's elder son. The First World War brought the company's production to a standstill, though in 1924 illuminated globes began to be manufactured thanks to Professor Albin Braf. Owing to the development of printing techniques and overall economic development after the war, many companies began to manufacture inexpensive and easily available globes, and as a result, Felkl's company was slowly losing the international market. The

\footnotetext{
1 The university was founded in 1364 as the Studium Generale, since 1400 known as the Kraków Academy, since 1817 as the Jagiellonian University.

2 According to a 1979 list, 56 globes from before 1800 were part of state and church collections, including 32 in scientific libraries and university museums (Piotr Grzegorz Ochman after Olszewicz, 1966/67, pp. 263-277).

3 In 1790, Klinger'sche Kunsthandlung started operating, since 1852 it was known as C. Abel Klinger Kunsthandlung.

4 J. Piasecka (1979a, b) mentions three globes, $15 \mathrm{~cm}$ in diameter, manufactured by Abel-Klinger: at the Polish Academy of Sciences in Warsaw, the University Library in Wrockaw and the Museum in Jędrzejów.
} 
transformation of the political system after the Second World War affected private businesses even more. In the aftermath of the Prague coup (in February 1948), communists took power and the repressive Stalinist regime came to rule (1948-1960). Then Jan Felkl's grand-grandson Vilém Otto Kraupner (19091979) ultimately decided to close the business (Mucha, 2002). Part of the company's equipment went to the National Museum of Technology in Prague, whilst some other elements were transferred to the Museum in Roztoky. After 1952, a factory manufacturing teaching aids was set up at the former company's premises, keeping Jan Felkl's original lithographic stones (Mucha, 1960, p. 245).

Table 1. Periods of operation of Jan Felkl's company.

\begin{tabular}{|c|c|c|}
\hline $\begin{array}{l}\text { Years in } \\
\text { operation }\end{array}$ & Signature & Managed by \\
\hline $1852-1870$ & Jan Felkl, Prague & Jan Felkl \\
\hline $1870-1874$ & $\begin{array}{l}\text { Jan Felkl, Roztoky } \\
\text { near Prague }\end{array}$ & Jan Felkl \\
\hline $1875-1952$ & $\begin{array}{l}\text { Jan Felkl i syn, } \\
\text { Roztoky near Prague }\end{array}$ & \\
\hline $1875-1894$ & & $\begin{array}{l}\text { Jan Felkl and sons: } \\
\text { Christoph Zikmund Felkl } \\
\text { Ferdinand Felkl, who managed the } \\
\text { company from } 1881\end{array}$ \\
\hline 1887 & \multicolumn{2}{|c|}{ Jan Felkl dies, his sons take over the business } \\
\hline | $1887-1894$ & & Christoph Zikmund Felkl \\
\hline $1894-1925$ & & Ferdinand Felkl \\
\hline $1914-1921$ & \multicolumn{2}{|c|}{$\begin{array}{l}\text { A break in the company's operation caused by the First } \\
\text { World War }\end{array}$} \\
\hline $1925-1929$ & & Katerina Felkl, Ferdinand's widow \\
\hline $1919-1939$ & & $\begin{array}{l}\text { Vilemina Marketa Kraupner, } \\
\text { Ferdinand's daughter }\end{array}$ \\
\hline $1939-1952$ & & $\begin{array}{l}\text { Vilem Otto Kraupner, Vilemina's } \\
\text { son }\end{array}$ \\
\hline 1952 & \multicolumn{2}{|c|}{ Vilém Otto Kraupner closes the business } \\
\hline
\end{tabular}




\section{Globes and maps by Jan Felkl's company}

Originally, the globe maps were printed in Prague (V. Šebek, K. Kutschner) and Leipzig (J. Kunsch) as hand-painted black-and-white lithographs. Around 1873, Jan Felkl set up his own Geographico-Litographical Institute in Prague, where they manufactured coloured lithographs. Until 1870 (when the company moved to Roztoky), the company offered ten kinds of terrestrial globes in eight sizes: $1.5,2.5,3.5,4.5,6,8,12$, and 18 inches in diameter. Originally, they were available in Czech and German language versions, and in 1861 the range was expanded to include Hungarian, Russian, Polish, Dutch and English language globes (Dörflinger, 1987). After 1877, maps were offered in seventeen language versions: Bulgarian, Croatian, Danish, Dutch, German, English, Hungarian, French, Polish, Italian, Spanish, Russian, Slovenian, Swedish, Norwegian and Romanian. Celestial globes were also manufactured, in four sizes: 4.5, 6, 8, and 12 inches in diameter (from the 1850s); as well as induction globes: 12 and 18 inches in diameter (from the 1860s); telluria (since 1858), lunaria (since 1860) and planetaria (since 1861). Professor Otto Delitsch (1821-1882), a German geographer and lecturer at the University in Leipzig, was the author of maps. After his death in 1882, J. Ǩehák, professor at a Czech higher education school, became the author of maps. The Czech terminology was developed by J. Erben, professor at a higher public school in Prague. In 1874, the Ministry of Education of Austria-Hungary recommended globes of 8-inch diameter as teaching aids in the first and second degree schools and 12-inch globes for all levels of education in the form of planetaria, telluria, lunaria and folding globes (Mucha, 1960, p. 244). Production went on for many years. The production of 8-and 12-inch globes, the only globes manufactured when Jan Felkl was still alive, was resumed after the First World War.

Simple globes were generally the most popular: the structure of such globes consists of a sphere set on an axis, a turned wooden column mounting with a circular foot, painted black or dark brown. Constructions with a brass meridian were a little more expensive. The globes on elaborate four-column or singlecolumn on tripod, with horizon (having polyhedron edges), an hour dial on the top, and sometimes also with a compass set on the base were the rarest. The globe with a meridian and a compass might cost twice as much as the plain model. Basic globes of 8-inch diameter might cost 7 florins 20 cents (kreutzers), whilst 
more elaborate globes as much as 14 florins 50 cents (kreutzers) 5 . The spheres of smaller globes (up to 4.5 inches in diameter) were made from cardboard, whilst 8 -inch and larger globes had plaster spheres.

\section{The first Polish-language globes}

The first Polish-language terrestrial globe was made in 1861. It was issued by a bookseller from Lviv (then Lemberg, Galicia), Jan Milikowski (1781-1866). ${ }^{6}$ The device was labelled "Kula Ziemska wydana przez J[ana] Felkla w Pradze, przet[ożyt] z niem[ieckiego] Franc[iszek] Waligórski" ("The terrestrial globe issued by J[an] Felkl in Prague, transl[ated] from German by Franc[iszek] Waligórski', diameter 8 inches, 1:60 000 000) (Piasecka, 1979b). None of such globes has survived; in literature it is mentioned as 'The globe with a brass meridian and a compass' (Estreicher, 1870, p. 490). In the period of Poland's Partitions, publishers and booksellers opposed deprivation of national identity by promoting intellectual awareness of cities and regions (Kost, 2011, p. 14). Jan Milikowski was a role model patriot bookseller at that time: he imported books and Polish magazines published in exile, including those banned by censorship, printed literature created in exile and commissioned translation of many foreign-language books into Polish. His bookshop was an important spot in the cultural and intellectual life of Lviv and a meeting place for men of letters and professors of the Lviv University. Milikowski was the main supplier of literature to Ossolineum (the Ossoliński National Institute in Lviv) (Kost, 2011, p. 14). He often supplied books to Polish schools in the region, as well as his native Cieszyn Silesia. When he was commissioned to publish the Polish-language version of the globe, this challenge was logically in line with his overall activity. The Polish-language version was translated from German by the Lviv poet Franciszek Waligórski (1824-1907), who since 1847 had worked for Gazeta Lwowska newspaper, an official organ in the Polish territory under Austrian rule. Originally he was a translator, and since 1848 a journalist at Gazeta. On his marriage certificate of 1851 , he declared himself as a 'translator' (Iwańska, 2013).

\footnotetext{
See Estreicher, 1870, p. 490. In the period 1857-1892, 1 florin equaled 100 kreutzers (cents). One hundredweight $(51.84 \mathrm{~kg}$ ) of salt cost 5 florin, $1 \mathrm{~kg}$ of bread 15 cents, $1 \mathrm{~kg}$ of butter 1 floren 16 cents (Kurpiewski, 1993).

6 In 1822, Jan Milikowski, together with Ignacy Kühn (?-1835), set up the company "Kühn i Milikowski" (25 Rynek, Lviv); after Kühn's death the company continued to operate under the name "Jan Milikowski". In 1849, he passed the management of the company to his sons Jan and Edmund, but still actively participated in managing the company.
} 
The next edition globe was issued in the years 1865-1867. It was the first globe with Polish terminology, built from scratch-ZIEMIA. Obrobit Mirostaw Suchecki. Wydat J. Felkl w Pradze czeskiej ('Earth. Compiled by Mirosław Suchecki. Issued by Jan Felkl in Prague, Bohemia, diameter 8 inches, 1:60 000 000) (Piasecka, 2003, p. 9). Mirosław Suchecki (1843-1912) was the son of the philologist and linguist Henryk Suchecki (1811-1872), who was a professor at the Charles University in Prague and the Jagiellonian University in Kraków ${ }^{7}$. Just like his father, Mirosław Suchecki pursued language studies. He published several works on linguistic issues, for example, the booklet Pisownia uchwalona a wymowa rodzima ('Official spelling versus local pronunciation,' Vienna, 1893). He was chiefly known as the author of a Polish stenography method. ${ }^{8}$ During his studies at the Institute of Technology in Prague, he worked at Jan Felkl's company, preparing terrestrial and celestial globes. He translated into Polish and edited Navedení, jak se má uživati umélých koulí zemskych $i$ nebeskych ('Guidelines for using globes of the Earth and sky', Jan Felkl, Prague, 1866) (under the Polish title: Wskazówka do używania globusów ziemskich i niebieskich, Prague, 1866). His name first appeared on the labels in the years 1898-1900. Suchecki lived until 1912, but in 1894 the company was passed on to Ferdinand Felkl, which initiated a period of the restoration of the company's prosperity. Most probably the globes followed revised maps that had been based on previous editions, so a few globes manufactured after 1898 have no Suchecki's name on their labels, but instead an empty space suggesting the information was deleted on the printing plate.

\section{Dating Jan Felkl's Polish-language maps and globes}

Felkl's globes are not dated, so an estimated date of their publication can only be guessed. Theoretically, a good way to identify the date is to analyse geographical names, but the Polish language grammar was codified throughout the $18^{\text {th }}$ and $19^{\text {th }}$ centuries. In the $18^{\text {th }}$ century Polish became compulsory as the teaching

7 Henryk Suchecki was the author of three Polish grammar books (mainly based of his own studies), recommended by the Imperial-Royal Ministry of Education for use in schools. In 1855, he was appointed head of the Chair of Polish Language and Literature at the Charles University in Prague.

8 In 1868, M. Suchecki lectured German stenography at the Jagiellonian University (then Kraków University). He also worked as a parliamentary stenographer for the Lviv Sejm. In 1866, in Prague, he published his Stenografia polska ('Polish stenography') which was not based on German stenography, as was the case with other systems used in Galicia. This system was also easy to apply to other Slavic languages and French (Essai d'un systeme facile de stenographie francaise, Vienna, 1905). 
language at schools of different levels ${ }^{9}$. Because of the introduction of Polish as a lecturing language on all levels of education, Polish language schoolbooks were needed, and what followed was the development of specialist terminology. After 1794 (the Third Partition of Poland), the Commonwealth of Two Nations ceased to exist as a state, but the same teaching methods were used in all the three partitioned parts of the country (under Russian and Austrian, and more rarely, Prussian rule), and later in designated areas which enjoyed various levels of autonomy (the Duchy of Warsaw, the Polish Kingdom, the Free City of Kraków, the Great Duchy of Poznań). Contacts between the regions were rather difficult and vocabularies in each region were strongly affected by the language of the ruling country. Until the times of King Stanisław Poniatowski (1764-1794), the spelling systems largely depended on the publisher, the printer, the reviewer and sometimes also the author (Malinowski, 2011, p. 48). It was being established throughout the entire $19^{\text {th }}$ century, until 1936. ${ }^{10}$ The use of letters $j, \dot{o}, \dot{e}, \dot{a}, \dot{z}$; diphthongs, double consonants, $x$ and $k s(g s)$ was the biggest problem. The manner of writing two-word names and the use of capital and small letters were also changing. Grammar-deriving adjectives, prepositions, etc.-was also modified. In 1930, a special commission was formed to establish standard spelling rules, but the changes after the First World War concern the times when Felkl's company no longer exported its products to the Polish market.

The use of the letter $j$ was discussed throughout the $19^{\text {th }}$ century. Initially, $j$ was used in words of foreign origin instead of the letter $g$ (jeografia). It was widely used when the globes were made, but the rules were rather ambiguous until 1936 (Saloni, 2005, p. 73). On the oldest globes we can see $y$ when $j$ is now used: Persya, Ceylon, Zatoka Victoryi, Nowa Holandya, Wyspy Maryañskie, whilst on others $j$ appears when $i$ is now used: Kolumbja, Hiszpanja, Algierja, Kyów. Names in which $b$ precedes a vowel-Morze Biate, Arabia —follow the rules which are also used now. There are also names in which we now use $y$ : Zatoka Siamska, Sydnej. The use of the letter $j$ on the maps on Felkl's globes is diversified. In some issues we see empty fields where the letter $j$ has been removed (deleted on

Professional books in Polish were printed in the period or the Reformation, see Geometria, to jest miernicka nauka po polsku krótko napisana z graeckich y z tacinskich ksiag ('Geometry or the measuring science in brief, after Greek and Latin books'; Kraków, 1566). Rev. Stanisław Konarski (1700-1773) started lectures in Polish in the newly established Collegium Nobilum (1741-1832), a school for the military. However, the Polish language became compulsory as a teaching language in all schools following the recommendation of the Commission of National Education set up in 1773. A set of Polish-language teaching books and teaching aids was developed by the Society for Elementary Books appointed by the Commission.

10 In view of continuing heated debates, in 1930 the Polish Academy of Arts and Sciences established an Orthography Committee in cooperation with the Ministry of Religious Denominations and Public Enlightenment. The Committee appointed seven problem commissions and in mid-1936 new regulations were endorsed by the Ministry (Malinowski, 2011). 
printing matrices) in such names as Austry_a, Szkocy_a, Irlandy_a, Mongoli_a.

Polish geographical terminology was another problem. Geography became an academic discipline in the $19^{\text {th }}$ century. In 1849 , the Chair of Geography was set up in Kraków, under Professor Wincenty Pol (historically, Europe's second Chair of Geography). It was in the period of Poland's Partitions, so creating a uniform system of Polish-language geographical terminology was impossible. Terms no longer in use can be seen on some globes, for example odnoga instead of zatoka (bay), wielowysep instead of archipelag (archipelago) or puszcza to describe desert areas (e.g., Puszcza Gobi). The presently used term pustynia (desert) can be seen on most of the globes, because the word puszcza means a vast forest area (Puszcza Białowieska, Puszcza Amazońska). South-Asian names were also rather confusing. Several versions of two main Chinese rivers may be seen: Hounghe, Jans Tse Kiong (4.5-inch diameter globe from 1866-1870), Houangho, Jang Cse Kiang (12inch diameter globe from ca. 1900) and Hoang-Ho, Yan-tse-Kiang. The Kunlun Mountains are either Kneu Lun (4.5 diameter globe, 1866-1870), Kieng Lin (8inch diameter globe, 1865-1884), or Kien Lin (12-inch diameter globe, ca. 1900).

Comparing Felkl's globes of $16 \mathrm{~cm}$ diameter (4.5 inches, $1: 80000$ 000), originating from the years 1866-1900, one can see that four different matrices (Table 2) were used to manufacture them.

Table 2. The names on some selected Felkl's globes (N- Nerlo, 1993).

\begin{tabular}{|l|l|l|l|l|}
\hline $\begin{array}{l}\text { Present } \\
\text { Polish name }\end{array}$ & $\begin{array}{l}1866-1870 \\
(\mathrm{~N})\end{array}$ & $188 ?-1894(\mathrm{~N})$ & $\begin{array}{l}1898-1900 \\
(\mathrm{~N})\end{array}$ & $\begin{array}{l}1866-1870 \\
\text { (Jagiellonian } \\
\text { University) }\end{array}$ \\
\hline Gujana & GUJANA & Gwajana & Gujana & Gujana \\
\hline Nepal & NEPAL & Nipal & Nipal & Nipal \\
\hline Meksyk & MEKSIKO & Meksik & Meksik & Meksiko \\
\hline
\end{tabular}

In 1890, folding globes began to be manufactured in three sizes: 22, 32, and $47.5 \mathrm{~cm}$. They were folded along the $20^{\circ}$ meridian west or along the equator. Inside there was a small induction globe. Following the trade offer from 1903: Preisliste der Lehrmittel Fabrik von J. Felkl \& Sohn, unfolding Polish-language globes in 22- and 32-cm diameter were manufactured (Nerlo, 1993). However, no such globe has been found.

Information about the company's 28 surviving Polish-language globes has been collected so far: 27 terrestrial globes and one celestial globe (Label 1). The 
Label 1. Information about the preserved globes.

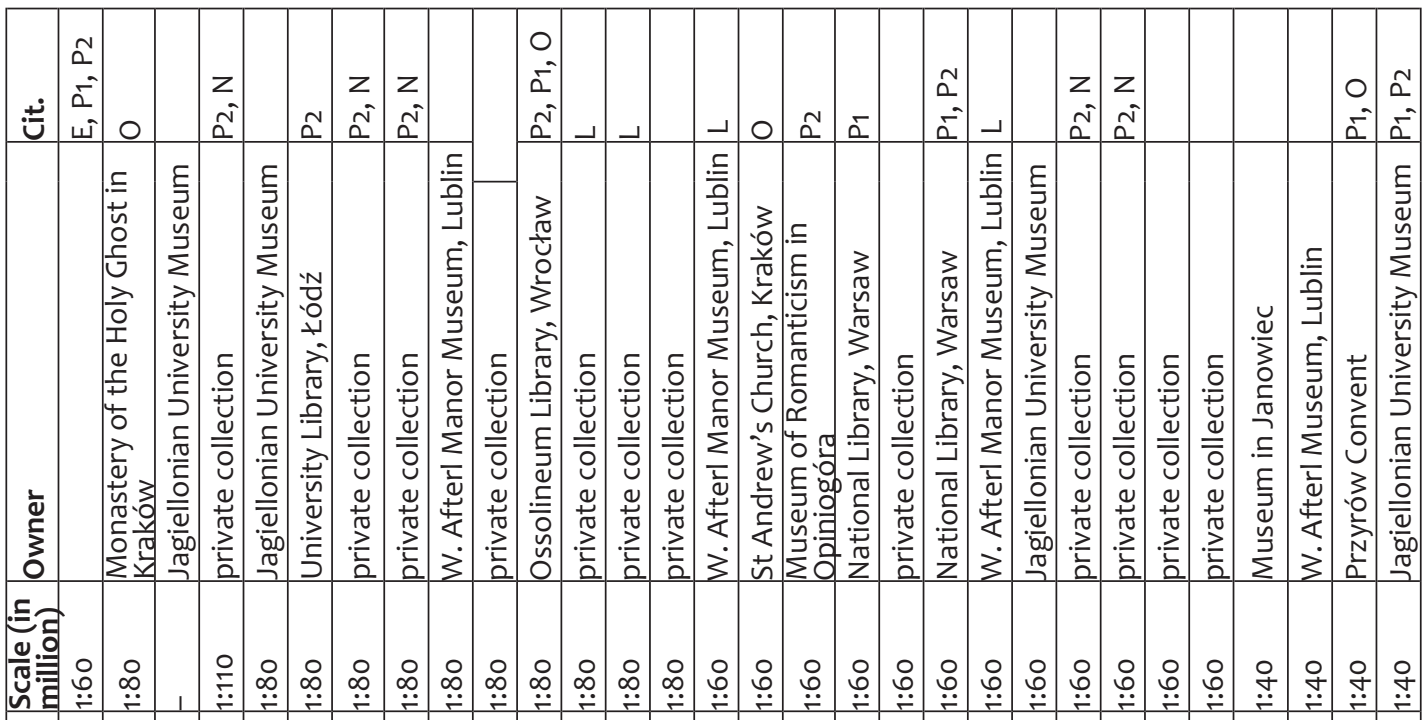

离

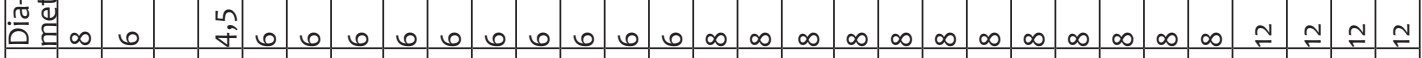

잉

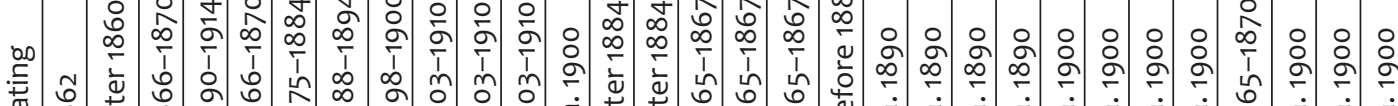

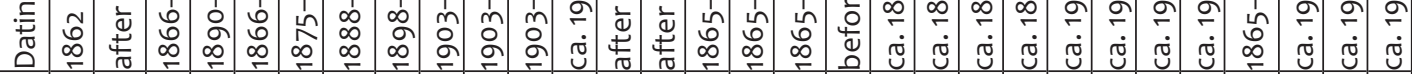

\begin{tabular}{|c|c|c|c|c|c|c|c|c|c|c|c|c|c|c|c|c|c|c|c|c|c|c|c|c|c|c|c|c|}
\hline & 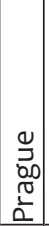 & 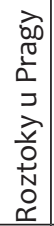 & 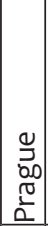 & 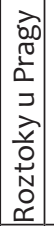 & 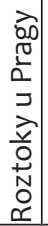 & 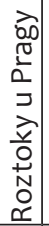 & 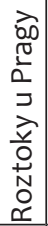 & 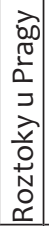 & 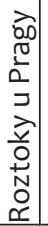 & 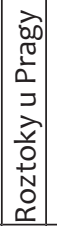 & 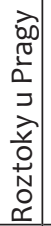 & 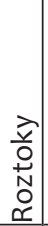 & 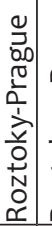 & 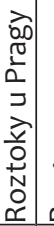 & & & 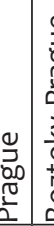 & 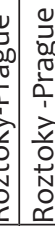 & 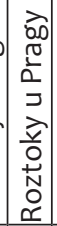 & 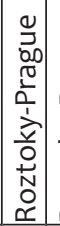 & 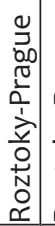 & 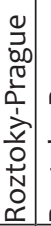 & 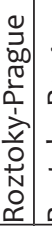 & 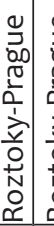 & 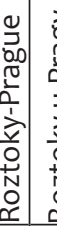 & 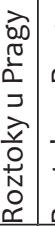 & 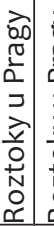 & \\
\hline है & 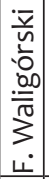 & & $\begin{array}{l}\dot{\bar{v}} \\
\mathbf{U} \\
\bar{y} \\
\bar{u} \\
\dot{\Sigma}\end{array}$ & & & 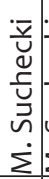 & 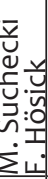 & 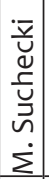 & & & & & $\begin{array}{l}\bar{y} \\
\stackrel{v}{u} \\
\underline{u} \\
\breve{v} \\
\dot{\Sigma} \\
\dot{\Sigma}\end{array}$ & & 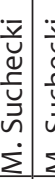 & 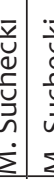 & 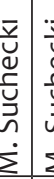 & 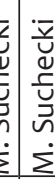 & $\begin{array}{l}\bar{y} \\
\bar{v} \\
\tilde{y} \\
\breve{v} \\
\dot{\Sigma}\end{array}$ & & & & & & & & & \\
\hline 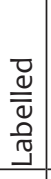 & \begin{tabular}{|l|}
$\bar{v}$ \\
$\stackrel{\bar{\nu}}{u}$ \\
$\dot{i}$ \\
\end{tabular} & $\begin{array}{l}\overline{\bar{y}} \\
\dot{\nu} \\
\dot{\dot{u}} \\
\end{array}$ & \begin{tabular}{|l}
$\overline{\bar{y}}$ \\
$\bar{\nu}$ \\
$\dot{\nu}$ \\
\end{tabular} & 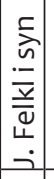 & 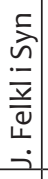 & $\begin{array}{l}\frac{5}{\sqrt[n]{n}} \\
\frac{\bar{z}}{\bar{v}} \\
\dot{\nu} \\
\dot{\nu}\end{array}$ & 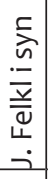 & 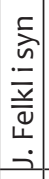 & 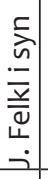 & 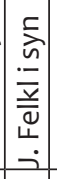 & 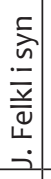 & 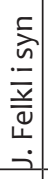 & 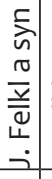 & 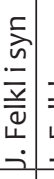 & 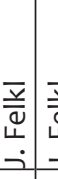 & $\begin{array}{l}\bar{y} \\
\\
\\
\dot{v}\end{array}$ & 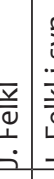 & 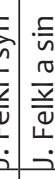 & 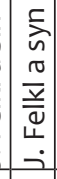 & 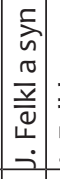 & 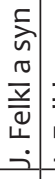 & $\begin{array}{l}\frac{\tilde{D}}{n} \\
\tilde{\sigma} \\
\bar{z} \\
\bar{v} \\
\dot{\nu} \\
\dot{i}\end{array}$ & $\begin{array}{c}\frac{5}{n} \\
\tilde{0} \\
\frac{v}{d} \\
\bar{\nu} \\
\dot{\nu}\end{array}$ & 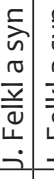 & 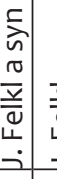 & 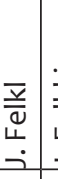 & 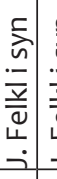 & $\frac{n}{n}$ \\
\hline $\begin{array}{l}\text { o } \\
\frac{0}{v}\end{array}$ & 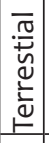 & 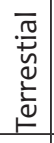 & 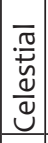 & 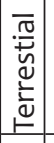 & 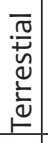 & 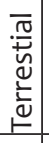 & 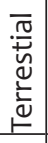 & 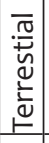 & 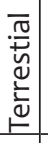 & 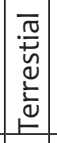 & 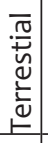 & 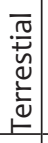 & 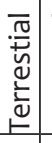 & 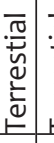 & 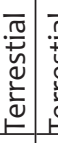 & 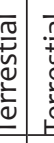 & 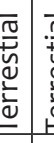 & 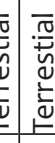 & 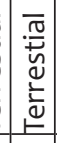 & 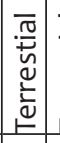 & 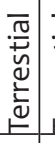 & 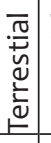 & 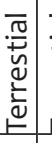 & 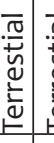 & 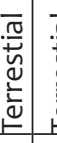 & 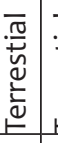 & 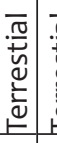 & \\
\hline & & مـ & $1-$ & & $m$ & $\sigma$ & $n$ & 0 & & $\infty$ & & 으 & $F$ & $\approx$ & $\stackrel{m}{-}$ & \pm & $\stackrel{n}{\sim}$ & $1-$ & $\underset{\sim}{\infty}$ & g & 이 & $\bar{\lambda}$ & $\tilde{N}$ & $\underset{\sim}{m}$ & ה & $\stackrel{\sim}{\sim}$ & $\begin{array}{ll}0 \\
\text { N }\end{array}$ & N \\
\hline
\end{tabular}

Sources: E - Estreicher, 1870; O - Olszewicz, 1966/67; P1 - Piasecka, 1979; P2 - Piasecka, 2006;

$\mathrm{N}$ - Nerlo, 1993 
sources published after the Second World War mention two more globes: the oldest dating from 1862 (no longer extant) and a globe 6 inches in diameter, allegedly kept at the Monastery of the Holy Ghost in Kraków. ${ }^{11}$ However, the monastery, the church and the hospital were demolished already in the $19^{\text {th }}$ century (1890-1892). Some furnishings were passed to the adjoining Church of the Holy Cross and to St. Andrew's Church. Unfortunately, no trace of the globe has been found.

Table 3. Polish-language globes against the company's production.

\begin{tabular}{|c|c|c|c|c|}
\hline \multicolumn{3}{|c|}{ Diameteres of globes on Felkl's offer ${ }^{1}$} & \multirow{2}{*}{$\begin{array}{l}\text { Surviving } \\
\text { Polish- } \\
\text { language } \\
\text { globes }\end{array}$} & \multirow[t]{2}{*}{ Comments } \\
\hline inch & $\mathrm{cm}($ ca. $)$ & scale & & \\
\hline 1.5 & 4 & 1: 320000000 & - & No information \\
\hline 2.5 & 6.2 & 1: 193063000 & - & $\begin{array}{l}\text { Known from } \\
\text { catalogues }\end{array}$ \\
\hline 3.5 & 8.6 & 1: 148165000 & - & $\begin{array}{l}\text { Known from } \\
\text { catalogues }\end{array}$ \\
\hline 4.5 & 11.4 & 1: 111774000 & 1 & \\
\hline 6 & 15.8 & 1: 80647000 & 10 & \\
\hline 8 & 21.9 & 1: 58183000 & 12 & $\begin{array}{l}\text { Including one } \\
\text { terrestrial globe }\end{array}$ \\
\hline 12 & 31.9 & 1: 40000000 & 4 & \\
\hline 18 & 47.5 & 1: 26826000 & - & $\begin{array}{l}\text { Manufactured } \\
\text { only in German, } \\
\text { Hungarian, Russian, } \\
\text { Czech and French- } \\
\text { language versions }\end{array}$ \\
\hline
\end{tabular}

The name Hösick (Hoesick) appears twice on the labels. Ferdynand Wilhelm Hösick (1835-1900) was a publisher and bookseller, who opened a bookshop in Warsaw. Later it was run by his son, also Ferdynand. On the globe 6 inches in diameter, dated to the years 1888-1894 (part of a private collection; Nerlo, 1993, p. 174), one can see the following information: ZIEMIA./ obrobit

$11 \quad$ After Olszewicz, 1966/67: the globe from 1862 on p. 78, the globe from the monastery on p. 276. 
Mirosław Suchecki./ Wydatl J. Felkl i syn Roztoky/ u Pragy/ F. HÖSICK/ w Warszawie ('EARTH/compiled by Mirosław Suchecki./ Published/ J. Felkl and Son, Roztoky/ u Pragy/ F. HÖSICK/ in Warsaw'). The second globe is larger, 12 inches in diameter, dated to $c a$. 1870. It is owned by the Vistula Museum in Kazimierz Dolny, the Janowiec Castle Branch. The label on the globe reads as follows: ZIEMIA./ Obrobitl Mirostaw Suchecki/ Wydat/ J. Felkl w Pradze czeskiej/ F. HÖSICK/ 496, Ulica Senatorska, 496/ w Warszawie ('EARTH/ Compiled by/ Mirosław Suchecki/ Published by/ J. Felkl in Czech Prague/ F. HÖSICK/ 496, Senatorska Street/ in Warsaw'). So far information about only one globe with an atypical label has been found: Felkl a sin (diameter 8 inches, $c a$. 1890, private collection). In other cases the Czech versions Felkl a syn or the Polish version Felkl i syn are seen.

The name of Mirosław Suchecki appears on 12 globes (11 terrestrial globes, and one celestial globe); other globes have labels with empty space (probably the name was deleted but unchanged on the printing plate) or with new signatures.

Of the surviving 28 globes, ten were manufactured during Jan Felkl's lifetime (four still in Prague, including the celestial globe, Fig. 1). The largest number was manufactured when Ferdinand Felkl managed the company. None of them were made after 1914 (a break in the company's operation caused by the outbreak of the First World War). As a result of the decision of the Treaty of Versailles, Poland reappeared on the world map. ${ }^{12}$ The first post-war globes were manufactured by Warsaw companies Pomoc Szkolna and Urania. Maps for both companies were printed by Zakład Artystyczno-Litograficzny Władystawa Główczewskiego, a company based in Warsaw, and were developed by its Cartographic Unit (Zakład Kartograficzny). At the same time, the publishing market developed in the country. Today we know that globes were made in Katowice (Katowickie Zaktady Drukarskie i Wydawnicze T.A., Kados company and its successor Pestalozzi), Poznań (Wydawnictwo Polskie), but first of all in Lviv (Eugeniusz Romer's Ksiażnica-Atlas).

12 During the Peace Conference in Paris (1919) Eugeniusz Romer (1871-1954) was an expert in geography appointed to the Polish delegation (1871-1954). When deciding on the borders of the Republic of Poland, Geograficzno-Statystyczny Atlas Polski ('Geographical and Statistical Atlas of Poland') his authorship (Vienna, 1916) was used. Eugeniusz Romer was the author of globes, and practically monopolised the Polish market. He based his atlases on hypsometric maps already in 1908. The globes were published from 1934: two physical globes (1:40 000000 in 1934 and $1: 50000000$ in 1935) and one political globe (1:100 000000 in 1935, second edition in 1938) were published before the Second World War. Together with the physical globe published after the Second World War (1:30 000 000, 1951, second edition 1959), they were models for further globes issued by Państwowe Przedsiębiorstwo Wydawnictw Kartograficznych until 1990s. 


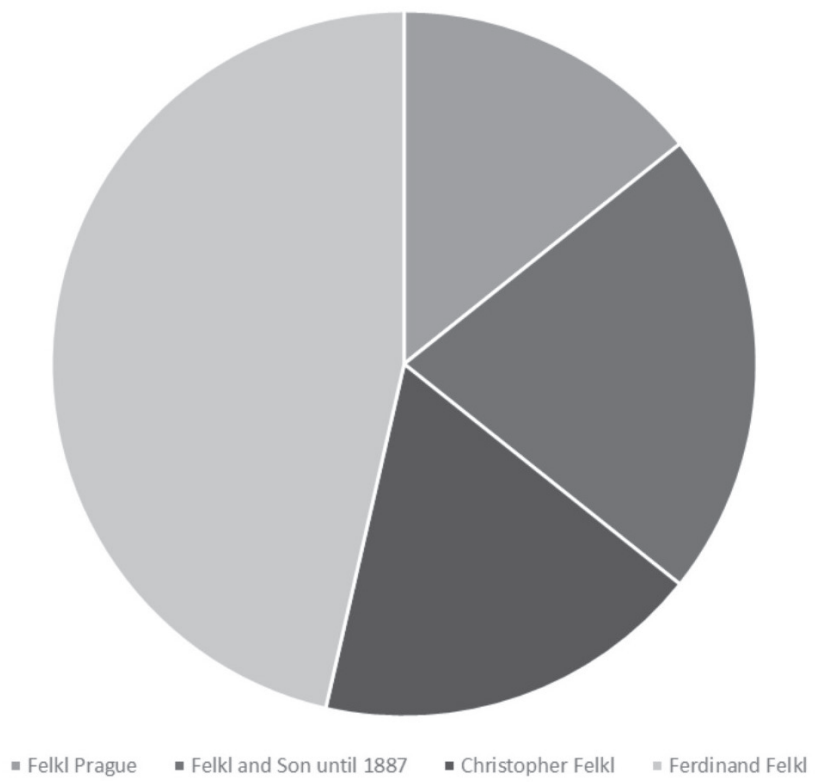

Figure 1. Production years of the preserved globes.

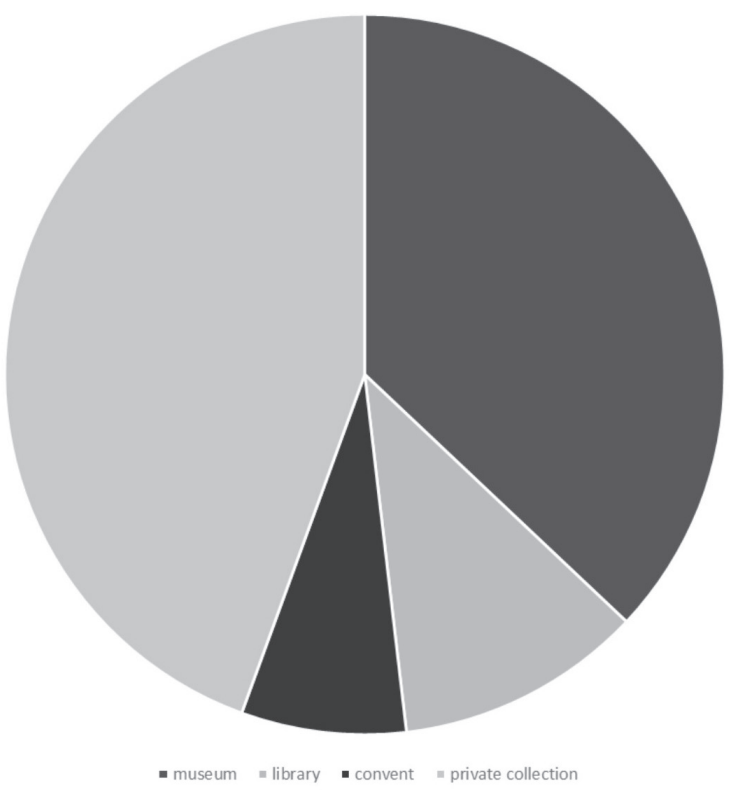

Figure 2. Property of the preserved globes. 


\section{The design and legacy of Jan Felkl's Polish-language globes}

Globes formed part of teaching aids manufactured by Felkl's company: planetaria, telluria and lunaria. In such cases, the globe diameters ranged from 1.5 to 12 inches. Some of them were designed for the Polish market because Mirosław Suchecki translated and edited Polish-language versions of manuals Objaśnienia stużace do planetaryjum J. Felkla ('Explanations to J. Felkl's planetarium'; Prague, 1866) and Objaśnienia stużace do telluryum z wyrobni I. Felkla ('Explanations to tellurium of J. Felkl's manufacture'; Prague, 1866) ${ }^{13}$. Unfortunately, no instruments with surviving globes have been found so far, as the latter must have been the most fragile elements in the entire instruments. Its cast-iron base, brass arms and mirrors could seriously damage plaster or cardboard spheres in transport and storage, in particular during wars and uprisings. However, calendar plates with their colours, decorations, fonts and terminology typical of Felkl's production have survived in good shape. Some, mostly German-language telluria and planetaria have also been found here and there. The Jagiellonian University Museum has a Polish-language tellurium. Probably there are more of them but without globes the function of such devices is unidentifiable, so they cannot be placed on official lists. It is difficult to say how many devices have survived in schools. According to oral accounts and students' memories, they must have been popular enough. However, of all the surviving globes made by the company, only one comes from a school other than a higher education establishment: the globe of 12-inch diameter (held at the Jagiellonian University Museum). ${ }^{14}$

In 1905, Towarzystwo Akcyjne Urzadzeń Szkolnych i Laboratoryjnych "Urania", and in 1912 the cooperative society Nasz Sklep were founded. In 1921, as a result of the merger of both firms, the company Nasz Sklep-Urania SA was established. Among other things, the company manufactured globes. Probably in the same period, lunaria and telluria began to be manufactured. The company's stock catalogue from 1929 mentions a lunarium (globe diameter $26 \mathrm{~cm}$ ), a tellurium-lunarium (globe diameter $18 \mathrm{~cm}$ ), three physical globes (each in two versions) and an induction globe. Thus Poland ceased to be a market for Felkl company's products.

The ownership situation of the surviving instruments is rather worrying (Fig. 2). Only ten are in museums and four in libraries, i.e. a half of the surviving devices.

13 Bibliografia Estreichara ('Estreicher's Bibliography'), $2^{\text {nd }}$ ed., p. 61, contains information that the instruction for the planetarium can be found in the Jagiellonian Library. Unfortunately it has not survived.

14 Donated to the Jagiellonian University Museum by the Queen Jadwiga Primary School from Nowy Sącz. 
There are twelve in private collections and two in convent collections.

In such cases artefacts are always at risk of dispersion when the successors take over the collection or if the owners experience financial problems. Polishlanguage objects may not be much sought after on international antique markets, but the experience of neighbouring countries shows that even if they are not in congress languages, there will always be a demand for them. Czechand Hungarian-language versions of Felkl's products appear on French, German and U.S. auction portals.

Our knowledge about the company's devices in Poland is only fragmented. In view of Poland's geographical situation, the country's history and political upheavals, few localities have remained unaffected since the mid-nineteenth century. Political unrest during the period of Poland's Partitions, both world wars, uprisings, resettlement of the population, etc. caused great losses in immovable and movable property. Major state and private archive resources were destroyed during the wars, so companies' advertising booklets, catalogues or leaflets can only rarely be found. In the course of resettlement and migrations, people usually left teaching aids behind, especially if they were not easy to transport. Few of them have made their way to Poland after the war. The globe $22 \mathrm{~cm}$ in diameter (from $c a .1937$ ), manufactured in Leningrad (Petrograd) in Pervaya Kartograficheskaya Fabrika Vshekhsoyuzn. Kart[ogra]Fichestva. GGGGUNK TL, Leningrad. Polskiy Yazyk, is one such example. It was brought to Poland by the Sisters of Nazareth who donated it to the Jagiellonian University Museum. It is probably the only surviving Polish-language device manufactured by the company (at least in today's Poland). The fact that the market for antiques is little formalised does not make the quest easy. Sometimes the objects appear on auction services, rarely in larger antique shops. Two of the four globes kept at the Jagiellonian University Museum were purchased within the last couple of years (2013 and 2014). However, private collectors are interested in such artefacts and spare no effort to improve their condition by commissioning professional renovation, which is a positive sign. 


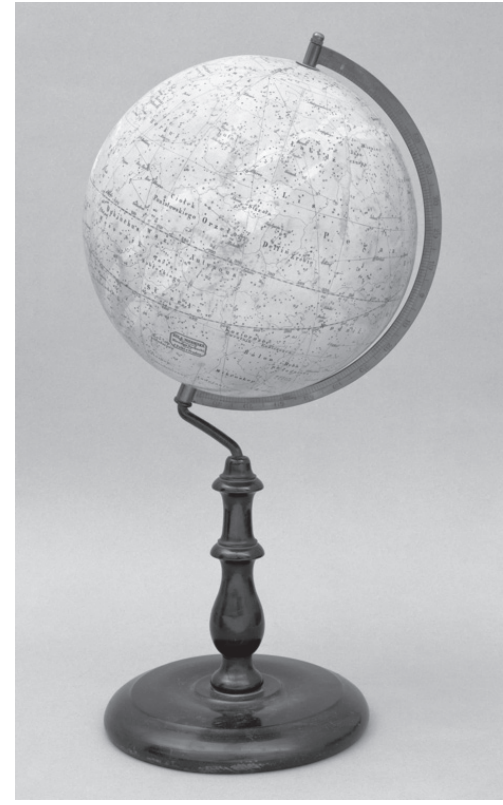

Celestial globe, J. Felkl, 18661870, Jagiellonian University Museum. Photo by Grzegorz Zygier.

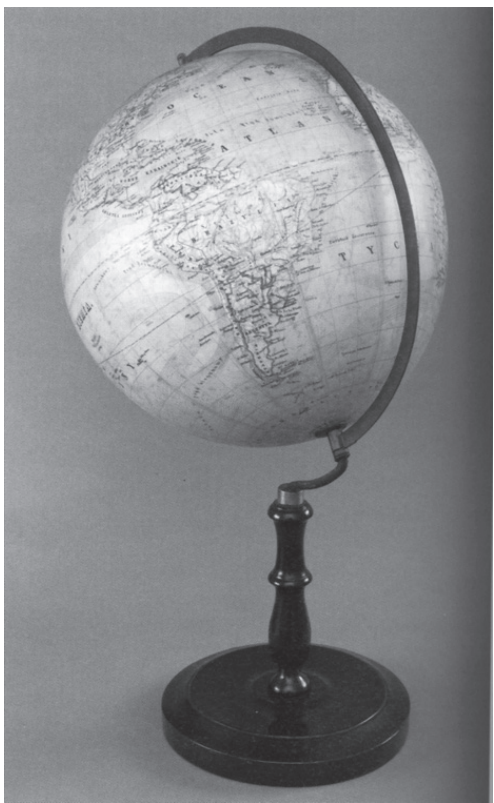

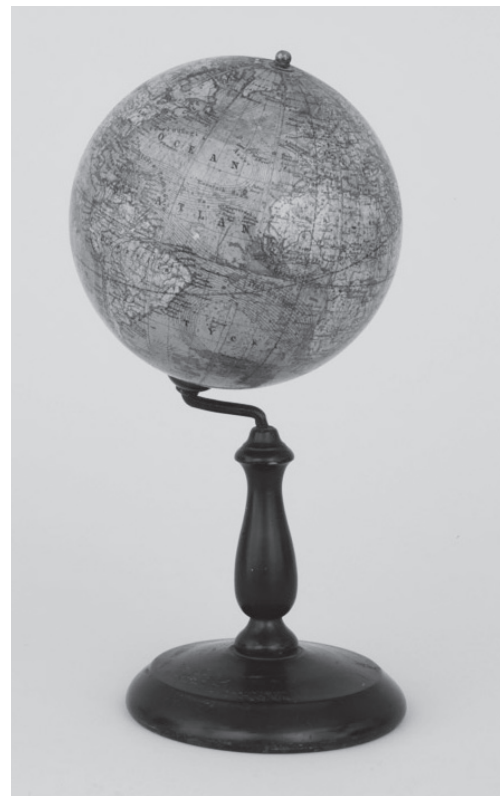

Terrestial globe, J. Felkl i syn, 1866-1870, diameter $6 \mathrm{~cm}$, Jagiellonian University Museum. Photo by Grzegorz Zygier.

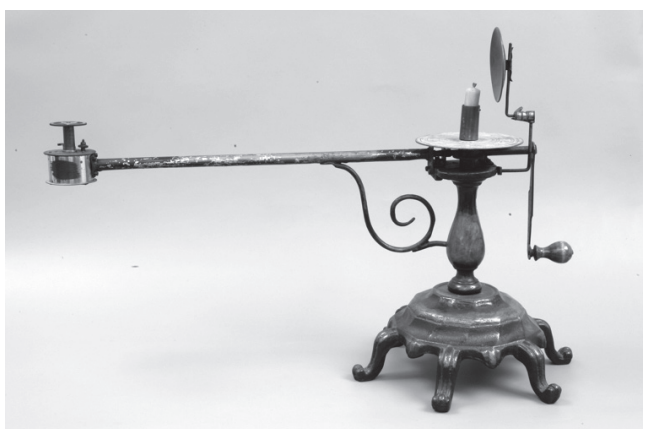

Tellurium, Jagiellonian University Museum. Photo by Grzegorz Zygier.

Terrestial globe, J. Felkl i syn, ca. 1900 , diameter 12 inches, Jagiellonian University Museum. Photo by Grzegorz Zygier. 


\section{Bibliography}

Dörflinger, J. (1987), 'Jan Felkl (1817-1887). Zum 100. Todestag eines altösterreichischen Globenfabrikanten,' Kartogr. Nachr., vol. 5, pp. 182-183.

Estreicher, K., jun. (1870), Bibliografia polska XIX w, tom I, Kraków: Nakładem Spółki Księgarni Polskich.

Iwańska, K. (2013), 'Franciszek Waligórski - poeta ze Lwowa i Krosna oraz jego potomkowie,' Wadowiana, vol. 16, pp. 4-5. Retrieved from http://wadoviana. eu/wp-content/uploads/2014/01/FRANCISZEK-WALIG\%C3\%93RSKI-K. Iwa\%C5\%84ska.pdf [accessed 12 Jan 2015]

Kost, B. (2011), 'Jan Milikowski. Rewolucyjny księgarz lwowski,' Kurier Galicyjski, vol. 5, no. 129 , pp. 14.

Kurpiewski, J. (1993), Zarys historii pieniądza polskiego, Warszawa: Polskie Tow. Archeologiczne i Numizmatyczne, Komisja Numizmatyczna.

Malinowski, M. (2011), Ortografia polska od II połowy XVIII wieku do wspótczesności. Kodyfikacja, reformy, recepcja, PhD thesis, Katowice: Uniwersytet Śląski. Wydział Filologiczny. Retrieved from http://www.sbc.org.pl/dlibra/ docmetadata?id=93088\&from=FBC [accessed 15 Jan 2015]

Mucha, L. (1960), 'The Czech globe-marker Jan Felkl,' Sbornik československé společnosti zemépisné, pp. 241-246.

(1985), 'Der tschechische Globenmacher Jan Felkl,' Der Globusfreund, vol. 33/34, pp. 122-142.

_ (2002), 'Vilém Otto Kraupner, poslední majitel Felklova závodu na výrobu glóbů, Národní Technické Muzeum v Praze,' 2002 Rozpravy Národního Technického Muzea v Praze, pp. 127, 174.

Nerlo, W. (1993), 'Nieznane polskie globusy Ziemi,' Polski Przeglad Kartograficzny, vol. 25 , no. 4, pp. 172-179.

Olszewicz, B. (1966/67), 'Alte Globen in Polen,' Der Globusfreund, vol. 15/16, pp. 263277.

Piasecka, J. (1979a), 'Die polnischen Erdgloben des 19. und 20. Jahrhunderts,' Der Globusfreund, vols. 25-27, pp. 237-239.

(1979b), 'Polskie globusy Ziemi z XIX i XX wieku,' Polski Przeglad Kartograficzny, vol. 11 , no. 2 , pp. 60-73.

_ (2003), Polskie globusy Ziemi z XIX i XX wieku, Lublin: Wydawnictwo Uniwersytetu Marii Curie-Skłodowskiej

Saloni, Z. (2005), 'O kodyfikacji polskiej ortografii- historia i współczesność,' Nauka, Kwartalnik Pan., vol. 4, pp. 71-96. 
Malgorzata Taborska is a biologist and surveyor, curator at the Jagiellonian University Museum since 2006. She is a supervisor of the collection of globes, clocks, sundials, watches as well as surveying, cartographical, meteorological instruments and biological laboratory equipment. She is interested in the history of science, especially the natural science and geodesy. 